\title{
Pemberian Air Rebusan Ketumbar terhadap Pengurangan Kadar Kolesterol pada Wanita di Desa Domas Kecamatan Menganti Kabupaten Gresik
}

\author{
Erma Retnaningtyas ${ }^{1}$ \\ ${ }^{1}$ Dosen Institut Ilmu Kesehatan STRADA Indonesia \\ Corresponding author: Erma Retnaningtyas (erma.retna26@gmail.com)
}

Received 16 August 2019; Accepted 20 August 2019; Published 5 September 2019

\begin{abstract}
ABSTRAK
Ketumbar merupakan salah satu rempah-rempah yang berkhasiat untuk terapi menurunkan kadar kolesterol . Kandungan asam linoleat, asam oleat, asam palmitat, asam stearat, dan asam askorbat pada ketumbar dapat menaikkan HDL. Kolesterol yang dibutuhkan oleh tubuh secara normal diproduksi sendiri dalam jumlah yang tepat. Kolesterol juga dapat meningkat jika sering mengkonsumsi makanan dengan kadar kolesterol tinggi. Penelitian ini menggunakan desain pra-eksperimen rancangan One Group pra test - post test design. Populasi yang digunakan sebanyak 48 responden, sample yang digunakan sebanyak 30 responden yaitu wanita dengan kolesterol di desa Domas. Menggunakan teknik Purposive Sampling. Pengumpulan data dilakukan dengan observasi dan dianalisis dengan menggunakan uji $\mathrm{T}$ dengan nilai $\mathrm{p}<0,05$. Dari hasil analisis didapatkan 19 responden mengalami penurunan kadar kolesterol, 8 responden kadar kolesteronya masih tetap, dan 3 responden mengalami kenaikan kadar kolesterol. Hasil statistic yang diperoleh dengan tingkat kemaknaan p value 0,000 sehingga dapat disimpulkan ada pengaruh pemberian air rebusan rebusan ketumbar terhadap penurunan kadar kolesterol. Hasil penelitian menunjukkan ada pengaruh pemberian air rebusan ketumbar terhadap penurunan kadar kolesterol dan dianjurkan mengkonsumsi air rebusan ketumbar secara teratur.
\end{abstract}

Kata Kunci: Kolesterol, Air Rebusan Ketumbar, Wanita dengan Kolesterol

Copyright @ 2019 Institut Ilmu Kesehatan STRADA Indonesia All rights reserved.

This is an open-acces article distributed under the terms of the Creative Commons Attribution-ShareAlike 4.0 International License.

\section{PENDAHULUAN}

Kolesterol merupakan suatu zat lemak yang beredar di dalam darah, berwarna kekuningan dan berupa seperti lilin, yang diproduksi oleh hati dan sangat diperlukan oleh tubuh. Kolesterol termasuk golongan lipid yang tidak terhidrolisis dan merupakan sterol utama dalam jaringan tubuh manusia. Kolesterol mempunyai makna penting karena merupakan unsur utama dalam lipoprotein plasma dan membran plasma serta menjadi prekursor sejumlah besar senyawa steroid (City \& Noni, 2013). Jika kadar kolesterol dalam tubuh berlebih akan mengakibatkan hiperkolesterolemia.

Data dari Badan Kesehatan Dunia (WHO) menunjukkan 20\% serangan stroke dan lebih dari $50 \%$ serangan jantung disebabkan oleh kadar kolesterol tinggi. Kasusnya di Indonesia meningkat per 
tahunnya sebanyak 28 persen dan menyerang usia produktif yaitu usia di bawah 40 tahun (Harian Rakyat Merdeka, 2013).

Menurut STP (Surveilans Terpadu Penyakit) di Jawa Timur penderita hiperkolesterolemia di Jawa Timur tahun 2011 sebanyak 285.724 pasien. 32.567 diantaranya adalah wanita usia subur. Sementara di Gresik sebanyak 986 wanita menderita kolesterol pada 2011.

Berdasarkan data dari bidan desa Domas, dari bulan Juli-Desember 2017, sebanyak 156 wanita menderita kolesterol. 63 orang berasal dari dusun Petal. 48 diantaranya adalah wanita. Pola makan adalah pemicu utama tingginya kolesterol pada wanita. Survey pendahuluan yang dilakukan oleh peneliti di dusun Petal, desa Domas, dari 5 responden yang menderita kolesterol diketahui bahwa semua cenderung mengkonsumsi obat-obatan daripada menggunakan pengobatan herbal. 2 responden mengkonsumsi obat secara rutin, sementara 3 responden megkonsumsi obat saat muncul gejala kolesterol tinggi.

Hiperkolesterolemia biasanya tidak menunjukkan gejala khas, seringkali seseorang baru mengetahui terkena hiperkolesterolemia ketika mereka melakukan pemeriksaan kesehatan ke pelayanan kesehatan atau karena keluhan lain. Hanya saja gejala yang sering ditemui yaitu sering pusing di kepala bagian belakang, tengkuk dan pundak terasa pegal, sering pegal, kesemutan di tangan dan kaki bahkan ada yang mengeluhkan dada sebelah kiri terasa nyeri seperti tertusuk. Jika hiperkolesterolemia ini dibiarkan begitu saja, akan meningkatkan risiko terjadinya penyakit jantung koroner dan stroke (Dadan, 2012).

Pencegahan hiperkolesterolemia sangat diperlukan karena prevalensi penyakit jantung di Indonesia yang cukup tinggi dan semakin meningkat. Secara non farmakologi untuk mencegah hiperkolesterolemia dilakukan dengan mengubah gaya hidup sehari - hari seperti mengatur pola makan yang seimbang dengan mengonsumsi buah-buahan atau sayur-sayuran, olahraga teratur, pengendalian berat badan, menghindari merokok, tidak minum alkohol, mampu mengatasi stress dengan tepat, menurunkan tekanan darah.

Selain perawatan medis, pengobatan tradisional bisa juga dilakukan untuk mencegah dan menurunkan kadar kolesterol yang tinggi. Selain itu pengobatan tradisional juga ekonomis dan mudah diperoleh (Hembing, 2008). Pengobatan tradisional terbukti secara alamiah aman dan bermanfaat dan dapat dikombinasikan dengan pengobatan konvensional sebagai pelengkap (komplementer) pelayanan kesehatan konvensional atau terapi pengganti (alternatif) bila terapi konvensional tidak bisa diberikan (Kemenkes RI, 2012).

Kandungan asam linoleat, asam oleat, asam palmitat, asam stearat, dan asam askorbat ternyata diketahui efektif menurunkan kadar kolesterol di dalam darah. Selain itu senyawa-senyawa tersebut mampu mengurangi deposit kolesterol dalam dinding pembuluh darah arteri dan vena. (Complementary Medicine and Drug Discovery, 2011).

Dalam upaya menurunkan kadar kolesterol pada batas normal pada penderita hiperkolestrolemia dapat diatasi dengan terapi farmakologis dan non farmakologis. Hiperkolesterolemia dapat diatasi atau dicegah dengan cara yang menarik, murah dan tentunya aman dikonsumdi. Salah satunya dengan mengkonsumsi air rebusan ketumbar yaitu salah satu terapi non farmakologis yang dapat digunakan untuk menurunkan kadar kolesterol dalam darah. Oleh karena itu peneliti tertarik untuk melakukan penelitian dengan judul "Pengaruh Pemberian Air Rebusan Ketumbar Terhadap Pengurangan Kadar Kolesterol Pada Wanita Di Desa Domas Kec. Menganti, Kab. Gresik”.

\section{BAHAN DAN METODE}

Metode penelitian yang digunakan dalam penelitian ini adalah penelitian pra-eksperimen rancangan One Group pra test - post test design untuk mengungkapkan hubungan sebab akibat dengan cara melibatkan satu kelompok subyek. Rebusan air ketumbar sebanyak 250ml akan diberikan kepada responden selama 7 hari. Pengecekan kolesterol akan dilakukaan pada hari ke-1 dan ke-7 pada masingmasing responden. 


\section{HASIL}

\section{Karakteristik responden}

Tabel 1 karakteristik responden berdasarkan usia dan pekerjaan

\begin{tabular}{c|c|c}
\hline Karakteristik & N & \% \\
\hline Usia & 2 & 7 \\
$20-25$ tahun & 10 & 33 \\
$26-35$ tahun & 18 & 60 \\
$36-45$ tahun & & \\
Pekerjaan & 21 & 70 \\
IRT & 1 & 3 \\
PNS & 8 & 27 \\
Swasta & & \\
\hline
\end{tabular}

Sumber : Hasil Analisa Data

\section{Karakteristik Variabel}

Tabel 2 Karakteristik Variabel sebelum dan sesudah pemberian air rebusan ketumbar

\begin{tabular}{ccc}
\hline Karakteristik & N & \% \\
\hline Sebelum & 30 & 100 \\
$200-240 \mathrm{mg} / \mathrm{dl}$ & 0 & 0 \\
$>240 \mathrm{mg} / \mathrm{dl}$ & 3 & 10 \\
Sesudah & 19 & 63 \\
Naik & 8 & 27 \\
Turun & & \\
Tetap & &
\end{tabular}

Sumber : Hasil Analisa Data

\section{Hasil Uji Statistik}

Hasil uji statistik Pengaruh Pemberian Air Rebusan Ketumbar Terhadap Pengurangan Kadar Kolesterol Pada Wanita Di Desa Domas Kec. Menganti, Kab. Gresik dengan uji T berpasangan dapat dilihat pada tabel dibawah:

\begin{tabular}{cll}
\hline No & & Variabel \\
1 & Kolesterol pre dan post & \\
2 & $\mathrm{n}=30$ & \\
3 & $\alpha=0,000$ & \\
\hline
\end{tabular}

Didapatkan dari Uji-T Berpasangan diperoleh nilai significancy 0,000 ( $\mathrm{p}$ value $<0,05$ ), sehingga $\mathrm{H} 0$ ditolak yang berarti ada pengaruh pemberian air rebusan ketumbar terhadap penurunan kadar kolesterol. 


\section{PEMBAHASAN}

\section{Kadar Kolesterol Dalam Darah Sebelum Diberikan Air Rebusan Ketumbar di Desa Domas Kecamatan Menganti Kabupaten Gresik}

Dari data hasil observasi yang telah dilaksanakan di desa Domas terhadap kolesterol sebelum diberikan air rebusan ketumbar pada wanita dengan kolesterol didapatkan bahwa 30 responden $(100 \%)$ memiliki kadar kolesterol $200 \mathrm{mg} / \mathrm{dl}-240 \mathrm{mg} / \mathrm{dl} .18$ responden (60\%) berusia diantara 36-45 tahun. 21 responden $(70 \%)$ diantaranya ibu rumah tangga.

Setelah dilakukan observasi sebelum pemberian air rebusan ketumbar, didapatkan semua responden memiliki kadar kolesterol 200mg/dl $-240 \mathrm{mg} / \mathrm{dl}$. Penyebab tingginya kolesterol dikarenakan gaya hidup dan pola makan yang kurang baik. Seperti mengkonsumsi makanan yang terlalu banyak mengandung minyak jenuh yang menyebabkan kadar kolesterol dalam darah meningkat. Yang tidak pernah disadari oleh responden karena beberapa makanan tersebut diyakini sehat seperti susu, telur, mentega dan lain-lain. Aktivitas yang kurang atau olahraga yang bisa dikatakan jarang dilakukan oleh responden bisa menyebabkan peningkatkan LDL (kolesterol jahat) dan penurunan HDL (kolesterol baik) serta ketidakmauan dalam mengkonsumsi obat-obatan untuk menurunkan kolesterol karena alasan tertentu seperti takut ketergantungan dengan obat-obatan. Terlalu banyak pekerjaan juga dapat menjadikan responden sedikit tidak memperhatikan kesehatannya.

\section{Kadar Kolesterol Dalam Darah Sesudah Diberikan Air Rebusan Ketumbar di Desa Domas Kecamatan Menganti Kabupaten Gresik}

Data hasil observasi yang telah dilaksanakan di desa Domas terhadap kadar kolesterol sesudah diberikan air rebusan ketumbar terhadap 30 responden selama 7 hari, terjadi penurunan kadar kolesterol yang sangat baik dari 30 responden,. diantaranya 19 responden kadar kolesterolnya turun, 8 responden dengan kadar kolesterol tetap dan 3 responden dengan kadar kolesterol naik.

Setelah diberikan rebusan air ketumbar terhadap 30 responden selama 1 minggu, terjadi penurunan kadar kolesterol pada 19 responden. Responden yang mengalami penurunan mengaku selain meminum rebusan air ketumbar juga melakukan tarak terhadap makanan yang dapat meningkatkan kadar kolesterol. 8 responden setelah di berikan rebusan air ketumbar menunjukkan kadar kolesterol yang tetap. Setelah dilakukan anamnesa diketahui responden sudah biasa meminum air rebusan ketumbar sehari-harinya. 3 responden setelah diberikan rebusan ketumbar menunjukkan kenaikan kadar kolesterol. Tetapi, kenaikan kadar kolesterol ini masih dalam batas normal, yaitu tidak lebih dari $240 \mathrm{mg} / \mathrm{dl}$. Kenaikan ini disebabkan oleh pola makan responden. Karena selama beberapa hari sempat mengkonsumsi makanan yang mangandung kolsetrol tinggi.

\section{Pengaruh Pemberian Air Rebusan Ketumbar Terhadap Penurunan Kadar Kolesterol pada Wanita di desa Domas Kecamatan Menganti Kabupaten Gresik}

Hasil uji statistic menunjukkan bahwa ada pengaruh pemberian air rebusan ketumbar terhadap penurunan kadar kolesterol dalam darah. Hasil Uji-T yang telah dilakukan menunjukkan nilai significancy 0,000 ( $\mathrm{p}$ value $<0,05$ ), artinya ada pengaruh pemberian air rebusan ketumbar terhadap penurunan kadar kolesterol.

Selain bermacam cara diatas, factor kemauan dan motivasi diri sangat mempengaruhi turunnya kadar kolesterol dalam darah. Kemauan dan motivasi dalam diri seseorang sangat mempengaruhi corak perbuatan yang akan diperlihatkan. Kemauan dan motivasi ini erat pula hubungannya dengan perhatian yang dimiliki dalam diri seseorang, karena perhatian mengarahkan timbulnya kehendak positif dan negative pada seseorang. Untuk itu perlu ditingkatkan pula kemauan dan motivasi dari responden untuk tetap menjaga kolesterol dalam batasan yang telah dianjurkan. Kebiasaan dalam masyarakat seperti melakukan tarak terhadap makanan dengan kandungan kolesterol tinggi juga depat mencegah terjadinya peningkatan kadar kolesterol dalam darah. Selain itu, menjaga berat badan ideal, melakukan 
olahraga secara teratur, menghindari factor pemicu stress serta mengkonsumsi air rebusan ketumbar setiap hari bisa mengurangai kadar kolesterol dalam darah.

\section{SIMPULAN DAN SARAN}

\section{Simpulan}

Sebelum diberikan rebusan air ketumbar kadar kolesterol dalam darah pada 30 responden adalah $200 \mathrm{mg} / \mathrm{dl}-240 \mathrm{mg} / \mathrm{dl}$.

Sebagian besar responden 63,33\% (19 responden) mengalami penurunan kadar kolesterol setelah diberikan air rebusan ketumbar, 8 responden $(26,67 \%)$ kadar kolesterol tetap dan 3 responden (10\%) mengalami kenaikan kolesterol.

Hasil uji statistik didapatkan nilai $p$-value $=0,000$ yang berarti lebih kecil daripada nilai $\alpha=$ $0,05(\mathrm{p}=0,000<\alpha=0.05)$ artinya tolak Ho kesimpulannya ada pengaruh pemberian air rebusan ketumbar terhadap penurunan kadar kolesterol.

\section{Saran}

Bagi responden diharapkan agar mengkonsumsi air rebusan ketumbar secara teratur dan menjaga pola makan, menjauhi kebiasaan makan makanan yang berlemak, berolahraga secara teratur untuk menjaga kondisi tubuh selalu dalam keadaan prima.

Bagi tenaga kesehatan untuk yenaga kesehatan di Desa Domas sebaiknya menganjurkan kepada masyarakat untuk mengkonsumsi air rebusan ketumbar secara teratur dan berperilaku sehat demi menjaga kondisi fisik yang sejat.

Bagi lahan penelitian dapat digunakan sebagai masukan untuk meningkatkan kualitas kesehatan warga desa Domas.

Bagi peneliti selanjutnya diharapkan bisa meneruskan penelitian ini menjadi lebih luas dengan jumlah sampel yang lebih banyak dan variabel yang lebih beragam, seperti tarak makan, aktivitas dan lain-lain.

\section{KEPUSTAKAAN}

Abu Bakar, M., A., \& Kowalski, S., R. (2010). A Comparative Analysis of The Libyan national essential medicines list and the WHO model list of essential medicines. (https://creativecommons.org/licences/by-nc/3.0) diakses tanggal 15 November 2017.

Adam, J., M. (2009). Buku Ajar Ilmu Penyakit Dalam Jilid III Edisi V. Jakarta:Bali Penerbit FKUI.

Almatsier, \& Sunita. (2008). Penuntun Diet Edisi Baru. Jakarta: PT. Gramedia Pustaka Utama.

Arikunto, S. (2010). Prosedur Penelitian Suatu Pendekatan Praktik. Jakarta: Rineka Cipta.

Astawan, M. (2009). Sehat Dengan Hidangan Kacang dan Biji-Bijian. Cetakan 1. Jakarta: Penebar Swadaya.

Anna, L., K., (2010). 'Rendah, Kepatuhan Minum Obat Kolesterol' kompas.com.

URL:http://kesehatan.kompas.com/read/2010/06/03/13255042/Rendah. Kepatuhan Minum Obat Kolesterol (diakses tanggal 15 November 2017).

Bhatnagar, D., Soran, H., \& Durrington, P., N. (2008). Hypercholesterolaemia and Its Management. British Medical Journal, 337: 503-508.

City, A., \& Noni, O. (2013). DIASKOL JANTROKE (Diabetes Militus, Asam Urat, Kolesterol, Jantung dan Stroke). Yogyakarta:IN AzNA Books. Hal 30-35.

Earlenor, Bull, \& Morrel, J. (2010). Kolesterol. Jakarta: Erlangga.

Fauci, et al. (2008). Harrison's Principle of Internal Medicine. $17^{\text {th }}$ ed. New York. Me Graw-Hill, 1553-1554. 
Guyton, A., C., \& Hall, J., E. (2008). Buku Ajar Fisiologi Kedokteran. Edisi 11. Jakarta.

Hidayat. (2012). Metode Penelitian Kebidanan dan Teknik Analisa Data. Jakarta: Salemba Medika.

Kementrian Kesehatan RI. (2013). Profil Kesehatan Indonesia tahun 2012. Jakarta:

World Health Organization. Global Burden Of Stroke.

Nilawati, \& Sri. (2008). Care Your Self, Kolesterol. Jakarta: Penebar Plus.

Notoatmodjo. (2012). Metode Penelitian Kesehatan. Jakarta : Rineka Cipta.

Nursalam. (2008). Konsep dan Penerapan Metodologi Penelitian Ilmu Keperawatan. Jakarta: Salemba Medika.

P. Dhanapakiam, J., Mini Joseph, V., K., Ramaswamy, M., Moorthi, \& A. Senthil Kumar. (2008). Journal of Environmental Biology: The cholesterol lowering property of coriander seeds (Coriandrum sativum): Mechanism of action, Vol. 29(1), No. 53-56.

Poedjiadi, A. (2007). Dasar-Dasar Biokimia. Edisi Revisi. Jakarta: UI-Press.

Shabela, \& Rifdah. (2012). Pahami Waspadai Cegah \& Musnahkan Kolesterol. Klaten: Cable Book

Sugiyono. (2016). Metode Penelitian, Kuantitatif,Kualitatif dan R\&D. Bandung: PT. Alfabet.

Suparyanto. (2011). Wanita Usia Subur. Jakarta: Erlangga. 